ruling passion, the one idea, of $\mathrm{Mr}$. bankergrocer-member Rickford, let me make honourable mention of the good Duke of Buckingham, who, at the commencement, promised his assistance in the shape of $300 l$. When called on for his subscription, what did this leviathan of the aristocracy? Redeem his promise like a gentleman? No! He refused it like a Duke, alleging that the institution was a humbug, and wholly uncalled for by the necessities of the county. Who opened his eyes? Interdum stultus bene loquitur. I beg to subscribe myself, Sir, yours respectfully, Y. $\mathbf{Y}$.

COMPLAINT RESPECTING THE

OPHTHALMIC INFIRMARY.

To the Editor of THE LA NCET.

Sin,-Yesterday, in going down to Greenwich, I sat by a respectable man, who complained to his wife opposite to him, of the great pain he suffered from an application just made to his eyes. I entered into conversation with him, and think there are two circumstances he mentioned which are worthy of public notice. He had been for some time a patient under Mr. Guthrie, at the Charing Cross Ophthalmic Institution; and he observed to me, with great warmth, that too much was left at that institution to the young pupils, whereby much injury accrued, alike to the patients, and to the character of Mr. Guthrie. But what he chiefly complained of, having himself experienced its very injurious effects, was the employment of the same brush in using the lotion to the eyes of different patients. His own observation was. " that individuals with affections of the eyes, which were free from any discharge, -were frequently cursed with the additional evil of a discharge, in consequence of the brush applied to their eyes having previously been used to cases with discharges." This, unfortunately, had happened to himself. To my inquiry, if he could assure me of the truth of the foregoing statements, he replied that he was ready and willing to make an affidavit to their correctness. You will, I am sure, see the propriety of taking some notice of these facts, either by publishing this note, or offering a few editorial remarks upon them. I am, Sir, yours, \&c.

An Invalid Subscribre to London, Sept. 11, 1833.

The Lancet.*

* We are in possession of the real name and address of our correspundent, wto is a highly repectable nomber of the medical profession. ED. L.

\section{MR. EDWARDS AND MR. WEISS.}

\section{To the Editor of The LanceT.}

Sir,-I observe with pain, in the last No. (524) of your influential Journal, a letter from Mr. Weiss, a respectable and most ingenious cutler in the Strand, in which he makes some assertions touching the invention of the percussor. I shall not attempt to answer these assertions, as any further controversy upon the subject could not possibly make the inventor's claims more evident than they are at present. I cannot, however, refrain from observing, in reply to an improper insinuation thrown out by $\mathrm{Mr}$. Weiss, that the advocacy of Mr. Edwards, in regard to lithotripsy, has been perfectly disinterested; that his first papers on the subject were written prior to his acquaintance with Baron Heurteloup, and that he has never derived any einolument from his exertions in the cause, directly or indirectly. All who are in the slightest degree acquainted with Mr. Edwards, will consider a contradiction to such an insinuation as totally needless, for they well know that if he advocates any cause, it is because, after a sufficient investigation of the points connected with it, he feels himself able to do so conscientiously. I have the honour to be, Sir, your most obedient servant,

\section{T. T. Brgas.}

18, Holles Street, Cavendish Square, Sept. 16, 1833.

\section{SHAVING WITH LIME-LATHER.}

\section{To the Editor of The LANCET.}

Srm,-I have lately noticed, in one of the daily papers, a piece of intelligence which might be attended with mischievous consequences if acted on, and against which I hope you will caution the public. It is gravely announced, that some proprietor of gas-wolks has discovered a new and improved mode of shaving, which he successfully practises on his own person. His process being to apply over the beard a lather of lime and wates; and after a few minutes, to scrape it off with a blunt razor, or even with the edge of a thin piece of wood. Now-should any one the rash enough to make the experiment, he will certainly find that after applying the lather for a few minutes, he may, if he please, easily remove lime and beard and skin altogether, otherwise they must all remain, for the lime becomes firm, and without acting much on the hair, cau: 